\title{
Low incubation temperature successfully supports the in vitro bovine oocyte maturation and subsequent development of embryos
}

\author{
Uğur Şen ${ }^{1, *}$ and Mehmet Kuran ${ }^{1}$
}

* Corresponding Author: Uğur Şen Tel: +90-362-312-19-19, Fax: +90-362-457-60-34,

E-mail: ugur.sen@omu.edu.tr

${ }^{1}$ Department of Agricultural Biotechnology, Faculty of Agriculture, Ondokuz Mayis University, Samsun TR55139, Turkey

ORCID

Uğur Şen

https://orcid.org/0000-0001-6058-1140

Mehmet Kuran

https://orcid.org/0000-0002-5139-1721

Submitted Jul 31, 2017; Revised Nov 19, 2017; Accepted Nov 23, 2017
Objective: The aim of this study was to compare the effects of $36.5^{\circ} \mathrm{C}$ and $38.5^{\circ} \mathrm{C}$ incubation temperatures on the maturation of bovine oocytes and developmental competence of embryos. Methods: In experiment 1, oocytes were maturated in bicarbonate-buffered TCM-199 for 22 hours in a humidified atmosphere of $5 \% \mathrm{CO}_{2}$ in the air at either $36.5^{\circ} \mathrm{C}$ or $38.5^{\circ} \mathrm{C}$ and nuclear maturation status were determined. In experiment 2 , in vitro fertilized oocytes were allocated randomly into synthetic oviductal fluid medium with or without a mixture of $1 \mathrm{mM}$ L-glutathione reduced and 1,500 IU superoxide dismutase and cultured in a humidified atmosphere of $5 \% \mathrm{CO}_{2}, 5 \% \mathrm{O}_{2}$, and $90 \% \mathrm{~N}_{2}$ in the air at $38.5^{\circ} \mathrm{C}$ for 8 days.

Results: There were no significant differences between incubation temperatures in terms of oocyte maturation parameters such as cumulus expansion, first polar body extrusion and nuclear maturation. Incubation temperatures during in vitro maturation had no effects on developmental competence of embryos, but supplementation of antioxidants increased ( $\mathrm{p}<$ 0.05 ) developmental competence of the embryos. Blastocysts from oocytes matured at $38.5^{\circ} \mathrm{C}$ had comparatively higher inner cell mass, but low overall and trophectoderm cell numbers $(\mathrm{p}<0.05)$.

Conclusion: The results of present study showed that maturation of bovine oocytes at $36.5^{\circ} \mathrm{C}$ may provide a suitable thermal environment for nuclear maturation and subsequent embryo development.

Keywords: Bovine; In vitro Maturation; Culture Temperatures; Antioxidants; Embryo Development

\section{INTRODUCTION}

Many researchers have investigated conditions required to improve in vitro maturation (IVM) and subsequent development of cattle oocytes [1,2]. In this respect various supplements to culture media have been examined including serum [3], follicular fluid, co-culture [4], growth factors and/or gonadotropic hormones [2]. However, IVM of bovine oocytes is not only related to the constituents of the culture medium but also to the incubation temperature [5]. A basic variable in the cellular environment of in vitro cultures is temperature [4]. Conventional in vitro bovine embryo production technology including oocyte maturation, fertilization and embryo culture is performed at $38.5^{\circ} \mathrm{C}$ or $39^{\circ} \mathrm{C}$ which represents core body temperature of cattle [6]. However, Leese et al [5] reported that preovulatory follicles have a temperature of approximately $1.5^{\circ} \mathrm{C}$ to $2^{\circ} \mathrm{C}$ less than that of the ovarian stroma or core body temperature in cattle, but this fact is rarely or never taken into account in in vitro embryo production. Moreover, McEvoy et al [7] suggested that present in vitro oocyte maturation technology is far from the in vivo reality due to incubation temperature employed. Also, Hunter et al [8] suggested that in vivo formation of meiotic and cytoplasmic maturation of oocyte, which occur at low temperature, should be considered in in-vitro studies. These phenomena lead 
to the suggestion that a temperature lower than core body temperature of cattle may provide better oogenesis or maturation of the bovine oocytes when cultured in vitro, and therefore, may result in an improvement in the subsequent development after fertilization.

Intra-cellular ATP production is realized as a result of oxidative metabolism, but also reactive oxygen species (ROS) are produced as undesired by-products of the process [9]. The amount of ROS production can vary depending on the rate of oxidative metabolism, and higher metabolic activity is associated with increased amounts of ROS production [10] that may cause cellular damage such as cellular enzymes inactivation, DNA damage and cell membrane lipid peroxidation in embryonic cells [5]. Generation of ROS is an unavoidable result of oxidative reactions, but various preservative scavengers such as superoxide dismutase, catalase and glutathione remove radical species before they can cause significant damage in in vitro embryo production systems. However, it would be possible to achieve a lower production of ROS with reduced metabolic activity and/or oxidative metabolism rate. In that case, culture media may require comparatively less or no supplementation with an antioxidant system against the ROS. Therefore, if environmental conditions of the in vitro culture of oocytes do not allow an increase in the rate of embryo metabolism, it may be possible to eliminate or reduce supplementations of the culture media with antioxidants. To this effect Leese [11] has put forward the 'Quiet Embryo Hypothesis', which proposed that low (quiet) embryo metabolism would better serve the embryo viability than active metabolism. This leads to the notion that the oocyte and the early embryo may function better at a lower temperature which is also representative of the in vivo preovulatory follicle environment [5]. Therefore, in this study we tested the hypothesis that exposure to lower temperature $\left(36.5^{\circ} \mathrm{C}\right)$ representative of the in vivo thermal conditions of the bovine preovulatory follicles, improves the maturation and subsequent post-fertilization development of the bovine oocytes. The main aim was to compare the effects of low $\left(36.5^{\circ} \mathrm{C}\right)$ and conventional $\left(38.5^{\circ} \mathrm{C}\right)$ culture temperatures on the oocyte maturation parameters and the embryonic development including the cell numbers, diameter and blastocyst quality.

\section{MATERIALS AND METHODS}

All chemicals and media used in this study were purchased from Sigma-Aldrich, Turkey, except where otherwise indicated.

\section{Collection and in vitro maturation of oocytes}

Within $3 \mathrm{~h}$ after slaughter bovine ovaries, which were collected from a local slaughterhouse, were transported to the laboratory in $0.9 \% \mathrm{NaCl}(\mathrm{w} / \mathrm{v})$ containing $0.1 \% \mathrm{v} / \mathrm{v}$ antibiot- ic solution (10,000 IU penicillin, $10 \mathrm{mg}$ streptomycin and 25 $\mu \mathrm{g}$ amphotericin $\mathrm{B}$ per $\mathrm{mL}$ ) at $33.2^{\circ} \mathrm{C} \pm 2.0^{\circ} \mathrm{C}$. Cumulus-oocyte complexes (COCs) were aspirated from follicles (2 to 8 $\mathrm{mm}$ in diameter) with an 18-gauge needle attached to a $10-\mathrm{mL}$ syringe. The COCs were collected in 3 to $4 \mathrm{~mL}$ Hepes-buffered TCM-199 (M7528; Sigma, Samsun, Turkey) containing Earle's salts and supplemented with $1 \% \mathrm{v} / \mathrm{v}$ antibiotic-antimycotic solution, $100 \mu \mathrm{g} / \mathrm{mL}$ L-glutamine and $5 \% \mathrm{v} / \mathrm{v}$ heatinactivated fetal calf serum (FCS). COCs were then classified as Grade A and Grade B according to previously described criteria [2]. Grade A COCs had homogeneous cytoplasm with an intact cumulus cells around oocytes and Grade B COCs had homogenous cytoplasm but an unevenly surrounding cumulus investment around oocytes. After classification, COCs were washed three times in Hepes-buffered TCM-199 and then twice in maturation medium. Maturation medium was sodium bicarbonate-buffered TCM-199 (M4530; Sigma, Turkey) containing Earle's salts and L-glutamine supplemented with $5.5 \mu \mathrm{g} / \mathrm{mL}$ sodium pyruvate, $1 \% \mathrm{v} / \mathrm{v}$ antibioticantimycotic solution, $10 \% \mathrm{v} / \mathrm{v}$ heat-inactivated FCS, $5.0 \mu \mathrm{g} / \mathrm{mL}$ luteinizing hormone, $0.5 \mu \mathrm{g} / \mathrm{mL}$ follicle stimulating hormone and $10 \mathrm{ng} / \mathrm{mL}$ epidermal growth factor. Grade A and Grade B COCs were separately placed in $500 \mu \mathrm{L}$ of maturation medium (approximately 25 to 35 COCs per well) covered with $300 \mu \mathrm{L}$ mineral oil in four-well culture dishes (Nunc, Roskilde, Denmark) and matured for 22 hours in a humidified atmosphere of $5 \% \mathrm{CO}_{2}$ in the air.

\section{Assessment of maturation parameters of oocytes}

Cumulus cell expansions of COCs were evaluated at the end of maturation period under a stereomicroscope. COCs with fully expanded cumulus cell layer were considered as maturated oocytes. After evaluation, COCs were washed three times in Hepes-buffered TCM-199. Subsequently, COCs were completely denuded of cumulus cells by vortexing and first polar body of oocytes was evaluated. Following, oocytes were fixed with a mixture of acetic acid: ethanol $(1: 3, \mathrm{v} / \mathrm{v})$ for $24 \mathrm{~h}$ at $4^{\circ} \mathrm{C}$ for evaluation nuclear status. The fixed oocytes were mounted on glass slides with $90 \%$ glycerol in Dtulbecco's phosphatebuffered saline (pH 7.4) containing 10\% (w/v) Hoechst 33342 (H-6024) at room temperature for $15 \mathrm{~min}$ and examined under fluorescent microscope. Excitation was induced at $365 \mathrm{~nm}$ and the emission was viewed through a 420 -nm barrier filter. Nuclear maturation was evaluated without knowing the treatment groups by an independent evaluator and classified as germinal vesicle $(\mathrm{GV})$, germinal vesicle breakdown (GVBD), metaphase I (M I) (including anaphase I and telophase I), metaphase II (M II) as described by Cevik et al [2].

\section{Spermatozoa preparation and in vitro fertilization}

Following maturation period, COCs were washed twice in Hepes-buffered TCM-199 and then twice in in vitro fertil- 
ization (IVF) medium. The IVF medium was glucose-free modified Tyrode's albumin lactate pyruvate (TALP; adjusted $\mathrm{pH} 7.4$ and 280 to $300 \mathrm{mOsm} / \mathrm{kg}$ ) supplemented with $25 \mathrm{mM}$ bicarbonate, $22 \mathrm{mM}$ Na-lactate, $1 \mathrm{mM}$ Na-pyruvate, $6 \mathrm{mg} / \mathrm{mL}$ fatty acid-free bovine serum albumin (BSA), $10 \mathrm{mg} / \mathrm{mL}$ heparin-sodium salt and $0.5 \mu \mathrm{L} / \mathrm{mL}$ antibiotic-antimycotic solution. COCs were transferred into $46 \mu \mathrm{L}$ IVF drops (approximately 15 COCs per drop) covered with mineral oil. Single bull frozen semen was used for IVF after thawed. Separation of motile sperm cells in the frozen-thawed semen was carried out by Percoll density gradient method. The sperm density was assessed by a hemocytometer using a phase contrast microscope at a magnification of $400 \times$ and adjusted to $50 \times 10^{6}$ spermato$\mathrm{zoa} / \mathrm{mL}$ with IVF medium. The sperm motility was visually checked for acceptable motility (at least $80 \%$ progressively motile). The oocytes were fertilized with $2 \mu \mathrm{L}$ diluted semen and $2 \mu \mathrm{L}$ of penicillamine, hypotaurine and epinephrine cocktail $(20 \mu \mathrm{M}$ penicillamine, $10 \mu \mathrm{M}$ hypotaurine, and $1 \mu \mathrm{M}$ epinephrine in final concentration) per IVF drop for 22 hours in a humidified atmosphere of $5 \% \mathrm{CO}_{2}, 5 \% \mathrm{O}_{2}$, and $90 \% \mathrm{~N}_{2}$ in air at $38.5^{\circ} \mathrm{C}$.

\section{In vitro culture}

After IVF, the putative zygotes were washed three times in Hepes-buffered TCM-199 and vortexed for 5 min to remove cumulus cells layer. The naked zygotes were washed twice in Hepes-buffered TCM-199 and then twice in synthetic oviductal fluid (SOFaa) embryo culture media. The SOFaa embryo culture media was supplemented with $40 \mu \mathrm{g} / \mathrm{mL}$ sodium pyruvate, $8 \mathrm{mg} / \mathrm{mL}$ fatty acid-free BSA, $20 \mu \mathrm{L} / \mathrm{mL}$ non-essential amino acids solution (100×), $10 \mu \mathrm{L} / \mathrm{mL}$ amino acids solution $(50 \times)$ and $0.5 \mu \mathrm{L} / \mathrm{mL}$ antibiotic-antimycotic solution on the day of use. The zygotes were placed in $50 \mu \mathrm{L}$ drops (approximately 15 zygotes per drop) of SOFaa embryo culture media under mineral oil and cultured in a humidified atmosphere of $5 \% \mathrm{CO}_{2}, 5 \% \mathrm{O}_{2}$, and $90 \% \mathrm{~N}_{2}$ in air at $38.5^{\circ} \mathrm{C}$. The IVF day was accepted as day 0 of embryonic development. Zygotes cleaved were determined on day 3 of development. Percentages of zygotes developed to morula and blastocyst stages were evaluated on days 5 and 8 , respectively.

\section{Determination of diameter and quality of blastocyst}

The diameter of each blastocyst was measured using a lens micrometer attached to an inverted light microscope $(\times 320)$. The quality of the blastocysts was determined according to the morphological criteria of International Embryo Transfer Society [12]. Blastocysts were categorized as Grade I; excellent or good quality blastocysts with blastocoele filling the entire blastocyst, compact inner cell mass (ICM), multicellular cohesive trophectoderm (TE) and oval shaped, Grade II; moderate quality blastocysts with normal ICM, but no optimal (fragmented or necrotic) TE, and Grade III; poor quality blas- tocysts with very few cells or without ICM and with large vacuole instead of blastocoel.

\section{Differential staining of inner cell mass and trophectoderm cells}

Differential staining was conducted as defined by Van Soom et al [13] and Sen [14]. A fluorescence microscope was used to view stained blastocysts (Nikon Invert Microscope Eclipse Ti-FL, 340 to $380 \mathrm{~nm}$ excitation and $430 \mathrm{~nm}$ suppression). ICM nuclei labelled with bisbenzimide appeared blue and TE nuclei labelled with both bisbenzimide and propidium iodide appeared pink to red. The numbers of ICM and TE nuclei were counted directly under the fluorescence microscope using a 345-nm ultraviolet light filter.

\section{Experimental design}

Experiment 1: Bovine oocytes were matured either at $36.5^{\circ} \mathrm{C}$ or $38.5^{\circ} \mathrm{C}$ on the same day and in different incubators for each replication and then the maturation parameters were examined as described above. Temperature of incubators was attentively set at the beginning of each experiment and the sample location was monitored continuously by means of thermometer in the incubator. The experiment was repeated 5 times.

Experiment 2: Bovine oocytes, matured either at $36.5^{\circ} \mathrm{C}$ or $38.5^{\circ} \mathrm{C}$, were subjected to IVF procedure. Following IVF, presumptive zygotes were cultured in SOFaa embryo culture medium supplemented with or without antioxidants (a mixture of $1 \mathrm{mM} \mathrm{L}$-glutathione reduced and 1,500 IU superoxide dismutase). The experiment was repeated 7 times.

\section{Statistical analysis}

Treatment effects (temperature) on maturation parameters of bovine oocytes were analyzed by chi-square $\left(\chi^{2}\right)$ test. Effects of temperature during IVM and antioxidants in embryo culture on developmental competence of embryos and cell numbers of blastocyst were analyzed by the general linear model of the SPSS 17.0 package program (SPSS, Chicago, IL, USA) after than arcsine-transformation and $\log 10$ transformation (cleaved embryos, morula and blastocyst yields were done arcsine-transformation; cell numbers of blastocyst were $\log _{10}$ transformation).

Quality of blastocysts was analyzed by chi-square $\left(\chi^{2}\right)$ test. Pearson correlation analysis were used for determine correlation between blastocyst diameter and cell numbers. Additionally, Kendall's Tau correlation analysis was applied for determine correlation between blastocyst diameter, development stages and quality. Duncan's test was used to determine differences between means, using a $p$ value of 0.05 and untransformed mean \pm standard error of the mean values were presented in Tables. Data on proportion of morula or blastocyst stages are presented as ratio of the numbers of morula or blastocysts to the number of cleaved zygotes. 


\section{RESULTS}

Effects of low incubation temperature during IVM on oocyte maturation parameters

The data on percentage of oocytes with expanded cumulus and first polar body extrusion (FPBE) are presented in Table 1. Low and conventional incubation temperatures in IVM had a similar effect on percentages of oocytes with expanded cumulus and FPBE in Grade A bovine oocytes. However, low incubation temperature during IVM decreased $\left(\chi^{2}=9.52 ; \mathrm{p}<\right.$ $0.05)$ percentage of FPBE in Grade B oocytes. Various nuclear stages of oocytes are presented in Table 2. Although there were no significant differences between the incubation temperatures during IVM in terms of nuclear maturation status of Grade A bovine oocytes, a lower percentage of Grade B oocytes $\left(\chi^{2}=12.14 ; \mathrm{p}<0.05\right)$ reached to M II stage at low incubation temperature during IVM.

Effects of low incubation temperature during IVM on zygote development

Development rates of bovine zygotes are presented in Table 3. The incubation temperature during IVM did not influence cleavage rate and proportion of embryos developed to blastocyst stage following IVF. However, percentage of zygotes developed to morula stage was significantly higher $(\mathrm{p}<0.05)$ in zygotes from oocytes matured at conventional tempera-
Table 1. Percentage of bovine oocytes with cumulus expansion and first polar body extrusion, matured in vitro either at $36.5^{\circ} \mathrm{C}$ or $38.5^{\circ} \mathrm{C}$ maturation temperatures

\begin{tabular}{|c|c|c|c|c|c|}
\hline \multirow{2}{*}{$\begin{array}{l}\text { Culture } \\
\text { temperature }\left({ }^{\circ} \mathrm{C}\right)\end{array}$} & \multirow{2}{*}{$\begin{array}{l}\text { Oocyte } \\
\text { quality }\end{array}$} & \multicolumn{2}{|c|}{ Cumulus expansion } & \multicolumn{2}{|c|}{ First polar body } \\
\hline & & $n$ & $\%$ & $n$ & $\%$ \\
\hline \multirow[t]{2}{*}{36.5} & Grade A & 623 & 96.2 & 78 & $79.5^{a}$ \\
\hline & Grade B & 687 & 89.8 & 108 & $63.0^{b}$ \\
\hline \multirow[t]{2}{*}{38.5} & Grade A & 622 & 95.8 & 82 & $85.4^{\mathrm{a}}$ \\
\hline & Grade B & 751 & 90.2 & 112 & $74.1^{\mathrm{a}}$ \\
\hline
\end{tabular}

a,b Different letters in the same column indicate significant difference $(p<0.05)$.

ture than those matured at low temperature. In experimental groups, developmental competence of zygotes was lower ( $\mathrm{p}<$ 0.05 ) in zygotes from Grade B oocytes than those of Grade A oocytes. Additionally, supplementation of antioxidants into embryo culture media improved blastocyst yield of embryos from Grade A oocytes $(\mathrm{p}<0.05)$.

\section{Effects of low incubation temperature during IVM on blastocyst formation}

Percentages of blastocyst quality are presented in Table 4 . The incubation temperature during IVM had no effect on blastocyst quality, but the antioxidant supplementation into embryo culture media improved blastocyst quality $(\mathrm{p}<0.05)$ only in zygotes from oocytes matured at conventional temperature. Percentage of Grade I quality blastocyst from Grade A oocytes

Table 2. Nuclear maturation status of bovine oocytes, matured in vitro either at $36.5^{\circ} \mathrm{C}$ or $38.5^{\circ} \mathrm{C}$ maturation temperatures per groups for 5 replicates

\begin{tabular}{lcccccc}
\hline \multirow{2}{*}{ Culture temperature $\left({ }^{\circ} \mathbf{C}\right)$} & \multirow{2}{*}{ Oocyte quality } & \multirow{2}{*}{ Oocytes $(\mathbf{n})$} & \multicolumn{4}{c}{ Nuclear maturation stages (\%) } \\
\cline { 4 - 7 } & & & GV & GVBD & M I & M II \\
\hline 36.5 & Grade A & 82 & $0(0)$ & $5(6.1)$ & $10(12.2)$ & $67(81.7)^{\mathrm{a}}$ \\
& Grade B & 72 & $3(4.2)$ & $9(12.5)$ & $18(25)$ & $42(58.3)^{b}$ \\
38.5 & Grade A & 88 & $1(1.1)$ & $3(3.4)$ & $18(20.5)$ & $66(75.0)^{\mathrm{a}}$ \\
& Grade B & 85 & $5(5.9)$ & $8(9.4)$ & $19(22.4)$ & $53(62.4)^{\mathrm{b}}$ \\
\hline
\end{tabular}

GV, germinal vesicle; GVBD, germinal vesicle break down; M I, metaphase I (including anaphase I and telophase I); M II, metaphase II.

$a, b$ Different letters in the same column indicate significant difference $(p<0.05)$.

Table 3. Effect of incubation temperatures during in vitro maturation and antioxidants in embryo culture media on developmental competence of embryos ${ }^{1)}$

\begin{tabular}{|c|c|c|c|c|c|c|}
\hline \multirow{2}{*}{ IVM condition $\left({ }^{\circ} \mathrm{C}\right)$} & \multirow{2}{*}{ Oocyte quality } & \multirow{2}{*}{ Antioxidants $^{2)}$} & \multirow{2}{*}{ Putative zygotes } & \multicolumn{3}{|c|}{ Developmental competence of bovine embryos (\%) } \\
\hline & & & & Cleaved & Morula & Blastocyst \\
\hline \multirow[t]{4}{*}{36.5} & Grade A & - & 215 & $68.4 \pm 2.42^{\mathrm{a}}$ & $45.0 \pm 2.60^{b}$ & $32.6 \pm 4.13^{b}$ \\
\hline & & + & 217 & $70.3 \pm 4.06^{\mathrm{a}}$ & $46.3 \pm 3.26^{b}$ & $37.8 \pm 5.52^{\circ}$ \\
\hline & Grade B & - & 215 & $56.0 \pm 3.34^{b}$ & $34.2 \pm 2.52^{c}$ & $21.7 \pm 3.95^{\circ}$ \\
\hline & & + & 219 & $49.8 \pm 5.62^{b}$ & $38.7 \pm 5.05^{c}$ & $18.5 \pm 2.66$ \\
\hline \multirow[t]{4}{*}{38.5} & Grade A & - & 194 & $71.7 \pm 2.46^{\mathrm{a}}$ & $57.4 \pm 5.57^{\mathrm{a}}$ & $29.8 \pm 2.57^{b}$ \\
\hline & & + & 205 & $78.0 \pm 2.05^{\mathrm{a}}$ & $58.3 \pm 4.64^{a}$ & $42.7 \pm 5.27^{2}$ \\
\hline & Grade B & - & 244 & $52.8 \pm 2.35^{b}$ & $39.6 \pm 3.68^{c}$ & $15.6 \pm 2.50$ \\
\hline & & + & 242 & $62.1 \pm 2.24^{b}$ & $34.4 \pm 2.93^{c}$ & $23.8 \pm 2.84$ \\
\hline
\end{tabular}

IVM, in vitro maturation.

1) Results are presented as untransformed mean \pm standard error of the mean values per groups for 7 replicates.

${ }^{2)}$ A mixture of $1 \mathrm{mM} \mathrm{L-glutathione} \mathrm{reduced} \mathrm{and} \mathrm{1,500} \mathrm{IU} \mathrm{superoxide} \mathrm{dismutase.}$

${ }^{a-c}$ Different letters in the same column indicate significant difference $(p<0.05)$. 
Table 4. Effect of incubation temperatures during in vitro maturation and antioxidants in embryo culture on blastocyst quality ${ }^{1)}$

\begin{tabular}{cccccc}
\hline \multirow{2}{*}{$\begin{array}{c}\text { IVM condition } \\
\left({ }^{\circ} \mathrm{C}\right)\end{array}$} & $\begin{array}{c}\text { Oocyte } \\
\text { quality }\end{array}$ & Antioxidants $^{2)}$ & \multicolumn{3}{c}{ Blastocyst quality (\%) } \\
\cline { 4 - 6 } & Grade I & Grade II & Grade III \\
\hline 36.5 & Grade A & - & $18.87^{\mathrm{a}}$ & 73.58 & $7.55^{\mathrm{b}}$ \\
& & + & $19.78^{\mathrm{a}}$ & 69.89 & $10.33^{\mathrm{b}}$ \\
& Grade B & - & $0.00^{\mathrm{c}}$ & 73.08 & $26.92^{\mathrm{a}}$ \\
& & + & $5.00^{\mathrm{c}}$ & 65.00 & $30.00^{\mathrm{a}}$ \\
38.5 & Grade A & - & $14.00^{\mathrm{b}}$ & 76.00 & $10.00^{\mathrm{b}}$ \\
& & + & $21.14^{\mathrm{a}}$ & 71.00 & $7.86^{\mathrm{b}}$ \\
& \multirow{2}{*}{ Grade B } & - & $4.17^{\mathrm{c}}$ & 66.66 & $29.17^{\mathrm{a}}$ \\
& & + & $0.00^{\mathrm{c}}$ & 72.97 & $27.03^{\mathrm{a}}$ \\
\hline
\end{tabular}

IVM, in vitro maturation.

1) Results are cumulative data from 7 replicates.

${ }^{2)} \mathrm{A}$ mixture of $1 \mathrm{mM}$ L-glutathione reduced and 1,500 IU superoxide dismutase.

${ }^{a-c}$ Different letters in the same column indicate significant difference $(p<0.05)$.

were higher $(\mathrm{p}<0.05)$ than those of Grade B oocytes.

Correlations between diameter and cell numbers, development stages and quality of bovine blastocysts Pearson correlation coefficients between diameter and various cell numbers of bovine blastocysts are shown in Table 5. The relationship between diameter and cell numbers of ICM were insignificant, but the positive correlations were detected between diameter and TE cell numbers $(0.710 ; \mathrm{p}<0.01)$, diameter and overall cell numbers of blastocysts $(0.798 ; \mathrm{p}<0.01)$, except for blastocysts from Grade A oocytes. Although there were no significant correlations between ICM and TE cell numbers of blastocysts, positive correlations were detected between overall cell numbers and TE cell numbers $(0.670 ; \mathrm{p}<0.05)$, and overall cell number and ICM cell numbers of blastocysts $(0.873$; $\mathrm{p}<0.01)$. Kendall's Tau correlation coefficients between diameter, development stages and quality of bovine blastocysts are presented in Table 6 . There was insignificant correlation between diameter and quality of blastocysts. The positive correlations were detected between diameter and blastocysts stages
Table 6. Kendall's Tau correlation coefficients (95\% confidence intervals) between diameter, development stages (early, mid, and expanded) and quality (grade I, II, and III) of blastocysts

\begin{tabular}{|c|c|c|c|c|c|}
\hline \multirow{2}{*}{$\begin{array}{l}\text { IVM } \\
\text { condition } \\
\left({ }^{\circ} \mathrm{C}\right)\end{array}$} & \multirow{2}{*}{$\begin{array}{l}\text { Oocyte } \\
\text { quality }\end{array}$} & \multirow{2}{*}{ Antioxidants $^{1)}$} & \multicolumn{3}{|c|}{ Traits } \\
\hline & & & $B D-B D S$ & $B D-B Q$ & $B D S-B Q$ \\
\hline \multirow[t]{4}{*}{36.5} & Grade A & - & $0.685^{* *}$ & -0.419 & 0.458 \\
\hline & & + & $0.733^{* *}$ & -0.498 & $0.650^{*}$ \\
\hline & Grade B & - & 0.501 & -0.501 & 0.375 \\
\hline & & + & 0.521 & -0.363 & 0.359 \\
\hline \multirow[t]{4}{*}{38.5} & Grade A & - & $0.706^{* *}$ & -0.417 & 0.452 \\
\hline & & + & $0.713^{* *}$ & -0.455 & 0.453 \\
\hline & Grade B & - & 0.581 & -0.509 & 0.385 \\
\hline & & + & 0.582 & -0.266 & 0.307 \\
\hline
\end{tabular}

IVM, in vitro maturation; BD, blastocyst diameter; BDS, blastocyst development stages; BQ, blastocyst quality.

${ }^{1)} \mathrm{A}$ mixture of $1 \mathrm{mM} \mathrm{L}$-glutathione reduced and 1,500 IU superoxide dismutase. ${ }^{*} p<0.05 ;{ }^{* *} p<0.01$.

obtained from Grade A oocytes (0.709; $\mathrm{p}<0.01)$. Moreover, when blastocyst development level advances from early to expanded or hatched blastocysts the diameter of blastocysts increases in all experimental groups $(\mathrm{p}<0.05)$.

\section{Effects of low incubation temperature during IVM on ICM, TE, and overall cell numbers}

ICM, TE, and overall cell numbers of bovine blastocysts are presented in Figure 1. The incubation temperatures during IVM did not affect ICM, TE, and overall cell numbers of blastocysts. However, antioxidant supplementation increased $(\mathrm{p}<$ 0.05 ) cell number of ICM in blastocysts from Grade A oocytes maturated at low incubation temperature. Also, TE and overall cell numbers were increased $(\mathrm{p}<0.05)$ by antioxidant supplementation in blastocysts from Grade A oocytes maturated at conventional incubation temperature. In all experimental groups, blastocysts produced from Grade B oocytes had lower $(\mathrm{p}<0.05)$ overall cell numbers than those of Grade A oocytes.

Table 5. Pearson correlation coefficients (95\% confidence intervals) between diameter and cell numbers of various parts of blastocysts

\begin{tabular}{|c|c|c|c|c|c|c|c|c|}
\hline \multirow{2}{*}{ IVM condition $\left({ }^{\circ} \mathrm{C}\right)$} & \multirow{2}{*}{ Oocyte quality } & \multirow{2}{*}{ Antioxidants ${ }^{1)}$} & \multicolumn{6}{|c|}{ Traits } \\
\hline & & & $B D-I C M$ & $\mathrm{BD}-\mathrm{TE}$ & $B D-O C N$ & ICM - TE & ICM - OCN & $\mathrm{TE}-\mathrm{OCN}$ \\
\hline \multirow[t]{4}{*}{36.5} & Grade A & - & 0.245 & 0.510 & 0.504 & 0.373 & 0.720 ** & $0.909 * *$ \\
\hline & & + & 0.528 & $0.883^{* *}$ & $0.891^{* *}$ & 0.069 & $0.629 *$ & $0.819 * *$ \\
\hline & Grade B & - & 0.482 & $0.644^{*}$ & $0.676^{*}$ & 0.161 & $0.671^{*}$ & 0.840 ** \\
\hline & & + & 0.507 & $0.781^{* *}$ & $0.843^{* *}$ & 0.080 & $0.651^{*}$ & $0.876^{* *}$ \\
\hline \multirow[t]{4}{*}{38.5} & Grade A & - & 0.504 & 0.730 ** & $0.815^{* *}$ & 0.259 & $0.614^{*}$ & 0.920 ** \\
\hline & & + & 0.433 & $0.777^{* *}$ & $0.712^{* *}$ & 0.395 & $0.728^{* *}$ & $0.924^{* *}$ \\
\hline & Grade B & - & 0.467 & $0.768^{* *}$ & $0.781^{* *}$ & 0.160 & $0.694^{*}$ & $0.889^{* *}$ \\
\hline & & + & 0.518 & 0.749 ** & $0.866^{* *}$ & 0.026 & $0.659^{*}$ & $0.814^{* *}$ \\
\hline
\end{tabular}

IVM, in vitro maturation; BD, blastocyst diameter; ICM, inner cell mass cell numbers; TE, trophectoderm cell numbers; OCN, overall cell numbers.

1) A mixture of $1 \mathrm{mM} \mathrm{L}$-glutathione reduced and 1,500 IU superoxide dismutase.

${ }^{*} p<0.05 ;{ }^{* *} p<0.01$. 


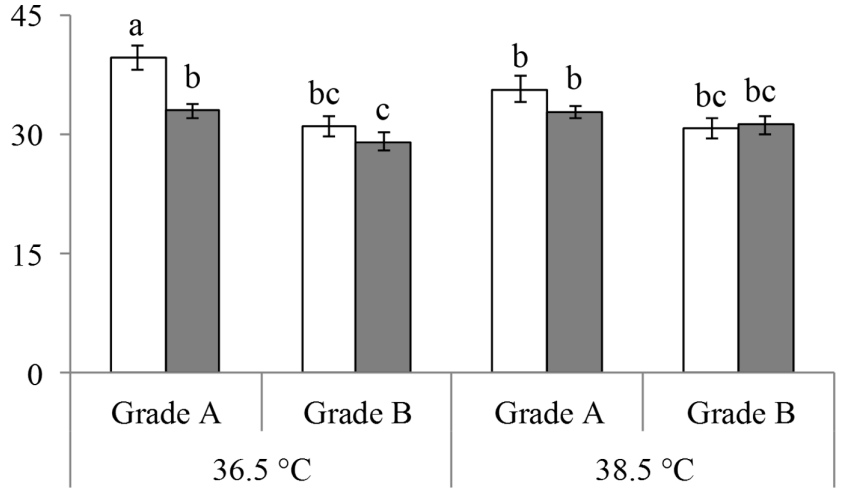

(a)

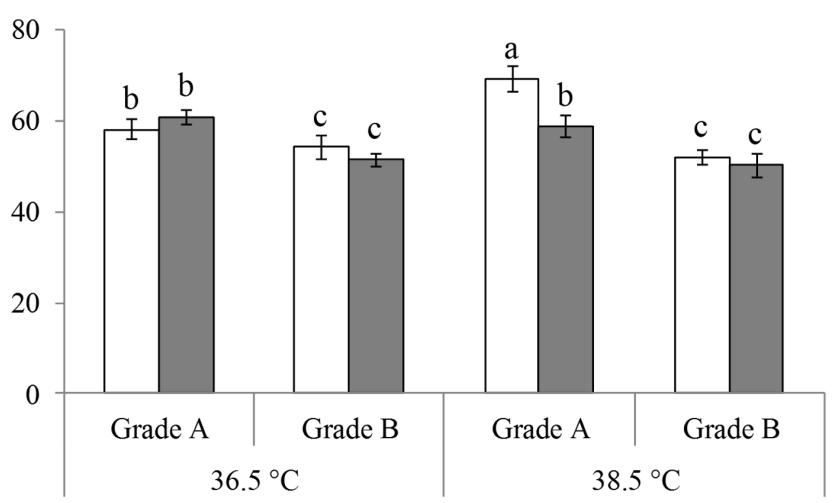

(b)

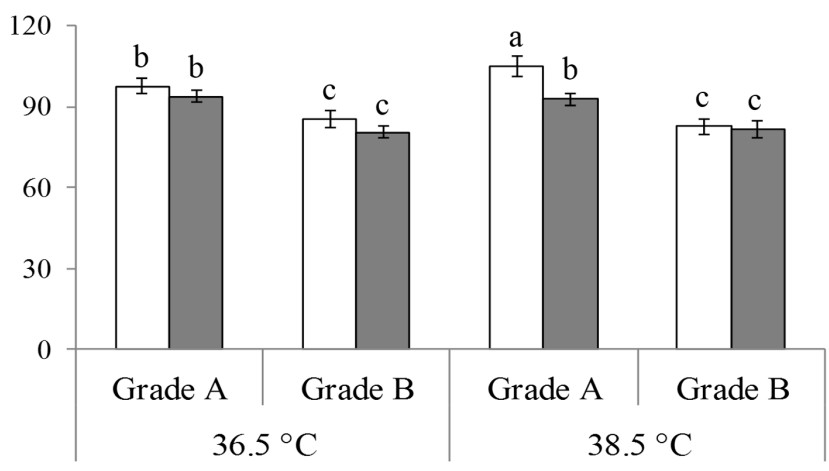

(c)

Figure 1. Effect of temperature during in vitro maturation and antioxidants in embryo culture on inner cell mass (a), trophectoderm (b), and overall (c) cell numbers of blastocysts from Grade A or Grade B oocytes matured at either $36.5^{\circ} \mathrm{C}(n=152)$ or $38.5^{\circ} \mathrm{C}(n=165)$. The error bars represent the standard error of means and bars with different letters are significantly different at $p<0.05$. The white bars represent the embryo culture media with antioxidants, whereas the gray bars represent the antioxidants free media.

\section{Effects of low incubation temperature during IVM on} blastocyst diameter

Diameter of bovine blastocysts is presented Figure 2. The incubation temperatures during IVM had no significant effect on blastocyst diameter at the end of embryo culture period, but supplementation of antioxidants into embryo culture media increased $(\mathrm{p}<0.05)$ diameter of blastocysts. Oocyte quality had significant effect on blastocyst diameter. The blastocysts

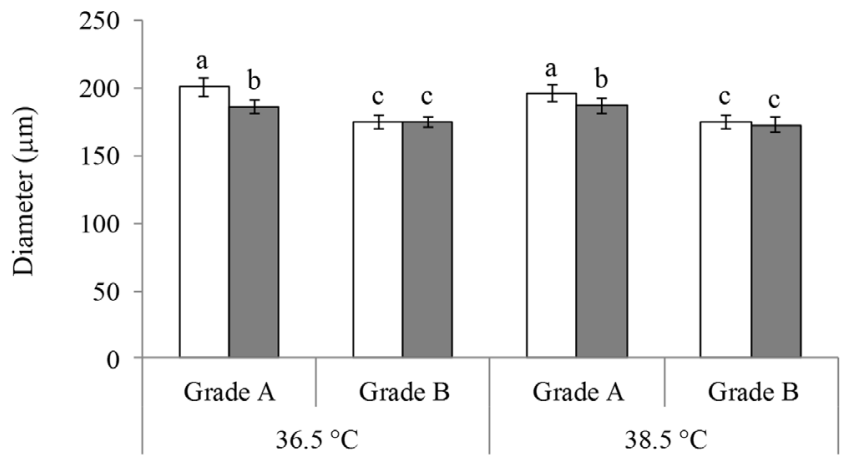

Figure 2. Effect of temperature during in vitro maturation and antioxidants in embryo culture on diameter of blastocysts from Grade A or Grade B oocytes matured at either $36.5^{\circ} \mathrm{C}(n=152)$ or $38.5^{\circ} \mathrm{C}(n=165)$. The error bars represent the standard error of means and bars with different letters are significantly different at $p<0.05$. The white bars represent the embryo culture media with antioxidants, whereas the gray bars represent the antioxidants free media.

obtained from Grade A oocytes had higher diameter than that of Grade B oocytes $(\mathrm{p}<0.05)$.

\section{DISCUSSION}

In the present study an attempt was made to carry out IVM of bovine oocytes at low temperature of $36.5^{\circ} \mathrm{C}$, which is considered to be the temperature of preovulatory follicles and at which supposedly in vivo oocyte maturation occurs. The results for the Grade A oocytes showed that cumulus expansion rate, first polar body formation and the proportion of oocytes reaching the $\mathrm{M}$ II stage were similar between the tested two maturation temperatures $\left(36.5^{\circ} \mathrm{C}\right.$ or $\left.38.5^{\circ} \mathrm{C}\right)$. This suggests that low incubation temperature of $36.5^{\circ} \mathrm{C}$ during the maturation process does not alter the progress of bovine nuclear maturation. Similarly, previous studies have shown that low incubation temperature during IVM did not affect the rate of cumulus expansion [15,16], first polar body formation [15-17] and proportion of oocytes that reached to M II stage $[4,6,15$, 16]. Ye et al [4] have reported that addition of follicular fluid to the maturation media did not alter nuclear maturation level of porcine oocytes matured at $35.5^{\circ} \mathrm{C}$, compared to counterparts matured at $39.0^{\circ} \mathrm{C}$ and $37.0^{\circ} \mathrm{C}$. Moreover, supplementation of estrous cow serum into the maturation media did not affect nuclear maturation level of bovine oocytes cultured at $37^{\circ} \mathrm{C}$ and $39^{\circ} \mathrm{C}[18]$. Overall, these studies suggest that serum may protect oocytes from possible negative effects, if any, of low incubation temperatures. It has been suggested previously [4] that, lower follicular ambient temperature is advantageous to complete oocyte maturation or development, within the follicular microenvironment. However, our results for Grade B oocytes have shown that low incubation temperature decreased the proportion of oocytes that reached M II or first polar body formed. These results suggest that lower 
temperatures do have negative impact on the maturation process which in our study was not obvious in the case of Grade A oocytes but was present in the case of comparatively vulnerable Grade B oocytes probably due to less cumulus cell layers which are known to assist in the nuclear maturation of mammalian oocytes [19].

As expected, embryos from Grade A oocytes had better developmental competence following IVF. Although cleavage rates of embryos obtained from oocytes matured at $36.5^{\circ} \mathrm{C}$ were similar to those from matured oocytes at $38.5^{\circ} \mathrm{C}$, the proportion of embryos in the morula stage were higher for Grade A oocytes matured at $38.5^{\circ} \mathrm{C}$. However, this difference disappeared at the blastocyst stage. Shi et al [6] have similarly shown that neither $37.0^{\circ} \mathrm{C}$ nor $38.5^{\circ} \mathrm{C}$ incubation temperatures during IVM had any significant effect on embryonic development until development to the blastocyst stage. Ravindranatha et al [16] reported that embryos from buffalo oocytes maturated at four different temperatures had similar development to 8 to 16 cells and blastocysts. Antioxidant supplementation, as expected, increased the ratio of embryos in the blastocyst stage, irrespective of maturation temperature whether the oocytes were maturated at $36.5^{\circ} \mathrm{C}$ or at $38.5^{\circ} \mathrm{C}$. Similar results on the effect of antioxidant supplementation have been informed by Luvoni et al [9] and Uysal et al [20].

The viability of the pre-implant embryo depends on a wellorganized formation of ICM cells [21]. Ganeshan et al [21] reported that in vitro environmental or culture conditions have primarily major effects at the developmental potential of the ICM cell lineage rather than the TE cell lineage. Previous studies reported that in vitro produced blastocysts had less ICM cells than in vivo counterparts [22,23]. Van Soom et al [13] and Kuran et al [24] reported that lower ICM or overall cell numbers of in vitro derived blastocysts are related to poor embryo quality. In the present study, incubation temperatures during IVM did not influence overall, ICM and TE cell numbers, but blastocysts obtained from Grade A oocytes matured at $36.5^{\circ} \mathrm{C}$ and cultured in antioxidants supplemented media, had more ICM cells. This could be a sign of an improvement in antioxidant defense system and low culture temperature during maturation had strengthened the antioxidant defense system in the morula and blastocyst stage of embryo development and may increase the quality of embryos. Additionally, this improvement may be caused by mimicking of the in vivo Graaf follicle environmental conditions. On the contrary, blastocysts, which were obtained from good quality oocytes matured at $38.5^{\circ} \mathrm{C}$ and cultured in antioxidant supplemented media, had more TE cells. These results indicate that bovine oocytes maturation in conventional culture temperature with antioxidant supplementations in embryo culture have improved subsequent development of embryonic TE cells from balancing the metabolic activity. Because, Hewitson and Leese [25] showed that TE cells consume more oxygen and nutrients due to having more mitochondria than the ICM cells. Also, ICM cells have more glycolytic metabolism than those of the TE in mouse embryo [25]. This low metabolic activity may reflect pluripotency of ICM cells [26]. Unfortunately, observations regarding to the embryo transfer and metabolic activity were not recorded in the present study. However future studies may help to interpret whether low maturation temperature had any effect on ICM cell metabolic activity and success rate of embryo transfer in cattle.

In the present study, we have observed that the incubation temperatures during maturation did not influence blastocyst diameter, but supplementation of antioxidants during embryo culture increased both overall cell number and diameter of blastocysts. In vitro produced blastocysts with a smaller diameter are known to have some anomalies in mitotic, osmotic or secretory activity of blastomeres [27]. Thus, these results of the present study may indicate that supplementation of antioxidants in embryo culture media may improve cell proliferation or the osmotic/secretory activity of the blastomeres in blastocyst rather than reflecting the culture temperatures during maturation stage.

In conclusion, the results of the present study demonstrated that bovine oocytes can complete maturation process at $36.5^{\circ} \mathrm{C}$ culture temperature and they exhibit similar embryonic development following IVF as the oocytes matured at conventional $\left(38.5^{\circ} \mathrm{C}\right)$ culture temperature. Low culture temperature during IVM could be useful to bovine in vitro embryo production programs. Future studies are required to investigate the effect of low incubation temperature during maturation on the metabolic activity, gene expression, DNA methylation and antioxidant capacity of both oocytes and embryos.

\section{CONFLICT OF INTEREST}

We certify that there is no conflict of interest with any financial organization regarding the material discussed in the manuscript.

\section{ACKNOWLEDGMENTS}

The authors acknowledge the financial support by the Ondokuz Mayis University Scientific Research Projects Coordination Unit (Project no: ZRT.1904.11.012) to carry out this study. We also thank Dr. Muhammad Khalid, Royal Veterinary College, and University of London, UK for his valuable critical editing of the manuscript.

\section{REFERENCES}

1. McDowall MLS, Gilchrist RB, Thompson JG. Cumulus expansion and glucose utilisation by bovine cumulus-oocyte 
complexes during in vitro maturation: the influence of glucosamine and follicle-stimulating hormone. Reproduction 2004; 128:313-9.

2. Cevik M, Sen U, Kocyigit A, Soydan E, Kuran M. Effects of serum, gonadotropins, epidermal growth factor and estradiol 17-beta on cumulus expansion and nuclear maturation of bovine oocytes. Kafkas Univ Vet Fak Derg 2011;17:1009-14.

3. Younis AI, Brackett BG, Fayrer-Hosken RA. Influence of serum and hormones on bovine oocyte maturation and fertilization in vitro. Gamete Res 1989;23:189-201.

4. Ye J, Coleman J, Hunter MG, et al. Physiological temperature variants and culture media modify meiotic progression and developmental potential of pig oocytes in vitro. Reproduction 2007;133:877-86.

5. Leese HJ, Baumann CG, Brison DR, McEvoy TG, Sturmey RG. Metabolism of the viable mammalian embryo: quietness revisited. Mol Hum Reprod 2008;14:667-72.

6. Shi DS, Avery B, Greve T. Effects of temperature gradients on in vitro maturation of bovine oocytes. Theriogenology 1998;50: 667-74.

7. McEvoy TG, Sinclair KD, Young LE, Wilmut I, Robinson JJ. Large offspring syndrome and other consequences of ruminant embryo culture in vitro: relevance to blastocyst culture in human ART. Hum Fertil 2000;3:238-46.

8. Hunter RHF, Grondahl C, Greve T, Schmidt M. Graafian follicles are cooler than neighbouring ovarian tissues and deep rectal temperatures. Hum Reprod 1997;12:95-100.

9. Luvoni GC, Keskintepe L, Brackett BG. Improvement in bovine embryo production in vitro by glutathione-containing culture media. Mol Reprod Dev 1996;43:437-43.

10. Sturmey RG, Hawkhead JA, Barker EA, Leese HJ. DNA damage and metabolic activity in the preimplantation embryo. Hum Reprod 2009;24:81-91.

11. Leese HJ. Quiet please, do not disturb: a hypothesis of embryo metabolism and viability. Bioessays 2002;24:845-9.

12. Stringfellow DA, Givens MD. International embryo transfer manual. A procedural guide and general information for the use of embryo transfer technology emphasizing sanitary procedures. 4th Edition 2013 with supplemental corrections. Savoy, MA, USA: IETS Publish; 2013.

13. Van Soom A, Ysebaert MT, Kruif AD. Relationship between timing of development, morula morphology, and cell allocation to inner cell mass and trophectoderm in in vitro produced bovine embryos. Mol Reprod Dev 1997;47:47-56.

14. Sen U. Effects of sperm from different bulls on developmental competence, blastosist quality and cell number of bovine embryos in vitro. Kafkas Üniv Vet Fak Derg 2015;21:339-44.
15. Lenz RW, Ball GD, Leibfried ML, Ax RL, First NL. In vitro maturation and fertilization of bovine oocytes are temperature dependent processes. Biol Reprod 1983;29:173-9.

16. Ravindranatha BM, Nandi S, Raghu HM, Reddy SM. In vitro maturation and fertilization of buffalo oocytes: effects of storage of ovaries, IVM temperatures, storage of processed sperm and fertilization media. Reprod Domest Anim 2003;38:21-6.

17. Eng LA, Kornegay ET, Huntington J, Wellman T. Effects of incubation temperature and bicarbonate on maturation of pig oocytes in vitro. J Reprod Fertil 1986;76:657-62.

18. Ocana QJM, Pinedo MM, Moreno MM. Influence of follicle size, medium, temperature and time on the incidence of diploid bovine oocytes matured in vitro. Theriogenology 1999;51: 667-72.

19. Maedomari N, Kikuchi K, Ozawa M, et al. Cytoplasmic glutathione regulated by cumulus cells during porcine oocyte maturation affects fertilization and embryonic development in vitro. Theriogenology 2007;67:983-93.

20. Uysal O, Akçay E, Tekin N. Effects of glutathione and superoxide dismutase on in vitro maturation, fertilization and culture of bovine oocytes. Indian Vet J 2003;80:758-62.

21. Ganeshan L, Li A, O'Neill C. Transformation-related protein 53 expression in the early mouse embryo compromises preimplantation embryonic development by preventing the formation of a proliferating inner cell mass. Biol Reprod 2010;83:958-64.

22. Iwasaki S, Yoshiba N, Ushijima H, Watanabe S, Nakahara T. Morphology and proportion of inner cell mass of bovine blastocysts fertilized in vitro and in vivo. J Reprod Fertil 1990; 90:279-84.

23. Du F, Looney CR, Yang X. Evaluation of bovine embryos produced in vitro vs. in vivo by differential staining of inner cell mass and trophectoderm cells. Theriogenology 1996;45: 211.

24. Kuran M, Robinson JJ, Brown DS, McEvoy TG. Development, amino acid utilization and cell allocation in bovine embryos after in vitro production in contrasting culture systems. Reproduction 2002;124:155-65.

25. Hewitson LC, Leese HJ. Energy metabolism of the trophectoderm and inner cell mass of the mouse blastocyst. J Exp Zool 1993;267:337-43.

26. Houghton FD. Energy metabolism of the inner cell mass and trophectoderm of the mouse blastocyst. Differentiation 2006; 74:11-8.

27. Kidson A, Rubio-Pomar FJ, Van Knegsel A, et al. Quality of porcine blastocysts produced in vitro in the presence or absence of GH. Reproduction 2004;127:165-77. 